\title{
EVALUASI KESESUAIAN LAHAN TANAMAN PADI DAN BUAH-BUAHAN BERDASARKAN AGROEKOSISTEM DAN AGROEKONOMI DI DESA TANGGUWISIA DAN JOANYAR, KECAMATAN SERIRIT, KABUPATEN BULELENG, BALI.
}

\author{
Ditamulia Slamet Utama \\ Fakultas Pertanian Universitas Flores \\ Kakek.gori@yahoo.com
}

\begin{abstract}
Agroecosystem and agroeconomic evaluation of land suitability for fruit and rice agriculture in Tangguwisia and Joanyar Village, Seririt District, Bali, Indonesia

This research was conducted in the Tangguwisia Village and Joanyar Village, Seririt District, Buleleng Regency, Bali, from January to April 2011. The goals of this study were to determine the suitability of land-based agroecosystems and agroeconomies for rice and fruit crops from an agroeconomic perspective and at the level of subclass, to understand the characteristics and qualities of land that allow for increased production of rice and fruits and to create thematic maps of land suitability for rice plant, banana, mango, rambutan, durian, and grape in the agriculturally viable area.

Land suitability was evaluated in several stages. First, a preparation phase was followed by the classification of land units (S1, S2, S3 and N). Agroecosystems with extremely agriculturally suitable soil were labeled (S1), systems with reasonably suitable soil were labeled (S2), systems with marginally suitable soil were labeled (S3) and systems considered completely unsuitable for agriculture were labeled (N). Sample points were determined and field surveys were conducted followed by soil analysis and data collection. This data was used to determine agroeconomic and agroecosystem suitability, and to make land use planning recommendations, all of which culminated in the production of a land suitability map.

Existing rice agroecosystems $\mathrm{S} 2, \mathrm{~S} 3$ and $\mathrm{N}$ were found to be suitable for rice, with slope and texture as limiting factors. Land sections S3 and $\mathrm{N}$ were found to be suitable for bananas, with rainfall, dry season length, texture, slope and erosion as limiting factors. Land sections S2, S3 and N were found to be suitable for mango agriculture with rainfall, texture, slope, surface rock, and erosion as limiting, banana, mango, rambutan, and durian). S1 was found to be most suitable to the growing of grapesfactors. Rambutan and durian cultivation were found to be best suited to the conditions in land unit $\mathrm{N}$, with rainfall and texture as limiting factors. Vines were found to be suitable in section S2, S3 and N, with dry season length, texture, drainage, slope and erosion as limiting factors. Land units S1 and S2 were found to be suitable to the widest variety of crops (rice).
\end{abstract}

Keywords: Land Suitability Evaluation, rice agriculture, fruits, agroecosystem, Agroeconomy, Tangguwisia Vilage, Joanyar Vilage 


\section{PENDAHULUAN}

Jumlah penduduk Provinsi Bali pada tahun 2000 mencapai 3.146.999 jiwa, dan pada tahun 2010 mencapai 3.891.428 jiwa, terjadi peningkatan jumlah penduduk Bali dari tahun ke tahun dengan laju pertumbuhan tahun 2000-2010 sebesar 2,15\% (Data BPS Provinsi Bali, 2010). Laju pertumbuhan penduduk yang tinggi harus dapat diimbangi dengan pemenuhan kebutuhan pangan yang meningkat dengan cara pengelolaan lahan pertanian secara intensif dan efisien.

Pengelolaan lahan pertanian secara intensif dan efisien tersebut tidak mudah dilakukan karena terbatasnya lahan pertanian yang dapat digunakan sehingga perlu adanya perencanaan penggunaan lahan yang tepat melalui perbaikan manajemen lahan. Dalam perencanaan penggunaan lahan diperlukan data karakteristik/kualitas lahan yang baik. Memperoleh data karakteristik/kualitas lahan salah satunya dengan cara melakukan penelitian evaluasi kesesuaian lahan.

Desa Tangguwisia dan Desa Joannyar merupakan desa yang berada di Kecamatan Seririt, Kabupaten Buleleng yang memiliki potensi dalam penyediaan produksi pangan berupa padi dan buah-buahan, hal tersebut dapat dilihat dari letak wilayah yang berdekatan dengan sumber air (sungai yang mengalir sepanjang tahun), berdekatan dengan pusat perdagangan (Kecamatan Seririt) dan memiliki wilayah yang cukup luas. Desa Tangguwisia memiliki luas 1,34 $\mathrm{Km}^{2} / 134$ ha, dengan pengunaan lahan sawah/lahan basah 11 ha, tegalan 104 ha, pekarangan 16,73 ha, kuburan 0,60 ha, tambak 0,25 ha, dan lainnya 1,42 ha, dengan produksi pertanian per tahun untuk padi 61,60 ton, durian 2,30 ton, mangga 2,50 ton anggur 550,50 ton, pisang 34,50 ton, rambutan 2,50 ton, dan tanaman lainnya 3,50 ton. Desa Joanyar memiliki luas $2,87 \mathrm{Km}^{2} / 287$ ha, dengan pengunaan lahan sawah/lahan basah 130,0 ha, tegalan 65,50 ha, perkebunan 78,0 ha, pekarangan 10,70 ha, kuburan 0,50 ha, tambak 0,30 ha, dan lainnya 2,00 ha, dengan hasil produksi pertanian pert tahun untuk padi 1693 ton, durian 2,60 ton, mangga 7,50 ton, anggur 7,50 ton, pisang 300,50 ton, rambutan 8,50 ton, dan tanaman lainnya 5,70 ton (Data BPS Kabupaten Buleleng, 2009). Data karakteristik/kualitas lahan Desa Tangguwisia dan Desa Joanyar belum diketahui, sehingga perlu dilakkukan penelitian evaluasi kesesuaian lahan.

\section{BAHAN DAN METODE}

Penelitian ini dilaksanakan pada bulan Januari 2011 hingga bulan April 2011 di Desa Tangguwisia dan Desa Joanyar, Kecamatan Seririt, Kabupaten Buleleng, Provinsi Bali.

Desa Tangguwisia dan Desa Joanyar merupakan desa yang letaknya berdekatan, berada di Kecamatan Seririt, Kabupaten Buleleng, Provinsi Bali. Secara geografis daerah penelitian terletak pada koordinat $08^{0} 10^{\prime} 38^{\prime \prime} \mathrm{LS}$ 08 13 '35'"LS, $\quad 115^{0} 56^{\prime} 32^{\prime \prime}$ 'BT $115^{\circ} 57^{\prime} 32$ 'BT. Secara administratif wilayah penelitian memiliki batas-batas, yaitu sebelah utara berbatasan

dengan Laut Bali, sebelah selatan berbatasan dengan Desa Rangdu, disebelah timur berbatasan dengan Desa Kalianget, Desa Banjar, dan Desa Mayong, dan disebelah barat berbatasan dengan Desa Sulanyah, Desa Bubunan, dan Desa Ringdikit. Desa Tangguwisia memiliki luas secara keseluruhan, yakni 134 ha, dan luas wilayah Desa Joanyar adalah 287 ha. (Data BPS Kab Buleleng, 2009).

Berdasarkan peta jenis tanah skala 1:250.000 Provinsi Bali (Program Studi Ilmu Tanah Fakultas Pertanian, 
Udayana) daerah tersebut memiliki jenis tanah Regosol. Daerah penelitian termasuk kedalam tipe iklim $\mathrm{F}$ dengan curah hujan rata-rata $1165 \mathrm{~mm} /$ tahun, bulan kering 6 bulan dan kelembapan $76,58 \%$ (Data Klimatologi LPHPT Tangguwisia, 2011).

Desa Tangguwisia memiliki pengunaan lahan sawah 11 ha, tegalan 104 ha, pekarangan 16,73 ha, kuburan 0,60 ha, tambak 0,25 ha, dan lainnya 1,42 ha. Wilayah desa Joanyar memiliki pengunaan lahan sawah 130,0 ha, tegalan 65,50 ha, perkebunan 78,0 ha, pekarangan 10,70 ha, kuburan 0,50 ha, tambak 0,30 ha, dan lainnya 2,00 ha (Data BPS Kabupaten Buleleng, 2009).

Bahan-bahan yang digunakan dalam penelitian ini adalah data curah hujan, data kelembaban, dan data temperatur (LPHPT Tangguwisia), peta jenis tanah Provinsi Bali skala 1 : 250.000 (Program Studi Ilmu Tanah Fakultas Pertanian, Udayana), peta penggunaan lahan Kecamatan Seririt skala 1 : 25.000 (Peta Rupa Bumi BOKUSURTANAL), peta kelas lereng Kecamatan Seririt skala $1: 25.000$ (Peta Rupa Bumi BOKUSURTANAL), buku kriteria kesesuaian lahan untuk komoditas pertanian Djaenudin, dkk., (2000), dan bahan-bahan kimia untuk analisis sampel tanah di laboratorium

Alat-alat yang digunakan dalam penelitian ini adalah bor tanah, ring sampel, pisau lapangan, GPS, kantong plastik, kertas label, $\mathrm{pH}$ meter untuk mengetahui kadar $\mathrm{pH}$ pada tanah di lapangan, Abneylevel, meteran, kertas dan pulpen dan alat-alat lab untuk analisis sampel tanah di laboratorium

Penelitian ini menggunakan metode evaluasi kesesuaian lahan dengan beberapa tahap penelitian yang dilaksanakan, yaitu tahap persiapan, delineasi satuan lahan, penentuan titik sampel, survei pendahuluan, survei lapangan, analisis tanah, tabulasi data, penentuan kesesuaian lahan Agroekosistem, penentuan kesesuaian agroekonomi, perencanaan arahan penggunaan lahan, dan pembuatan peta kesesuaian lahan aktual.

Tahap pengumpulan data penunjang seperti jurnal-jurnal, penelitian sebelumnya sebagai data sekunder untuk memperoleh informasi yang berhubungan dengan daerah penelitian. Pengumpulan peta-peta seperti peta jenis tanah, peta kelas lereng dan peta penggunaan lahan.

Delineasi satuan lahan homogen dilakukan dengan tumpang susun peta lereng skala 1:25.000, peta penggunaan lahan skala 1:25.000, dan peta tanah skala tinjau sebagai acuan, berdasarkan persamaan satuan lahan.

Penentuan pengambilan titik sampel dengan metode transek lereng. Sampel tanah diambil secara komposit untuk dilakukan analisis di laboratorium.

Melakukan penjelajahan di lokasi penelitian untuk mencocokkan hasil delineasi satuan lahan dengan keadaan dilapangan. Bila hasil delineasi satuan lahan homogen tidak sesuai dengan keadaan di lapangan maka langsung dilakukan perbaikan satuan lahan.

Melakukan survei di lapangan untuk mencari data fisik lingkungan dan sampel tanah, pengambilan sampel tanah berdasarkan titik-titik sampel pada satuan lahan yang sudah ditentukan, data pengambilan sampel meliputi pengambilan sampel utuh dengan ring sampel dan pengambilan tanah terusik menggunakan bor tanah dengan kedalaman 0-30 cm untuk penggunaan lahan sawah dan 0-60 cm untuk penggunaan lahan kebun campuran, kebun anggur dan tegalan, kemudian dimasukkan kedalam kantong plastik untuk nantinya dianalisis di laboratorium. Pengamatan data fisik lingkungan yang dilakukan adalah 
pengamatan kemiringan lereng, panjang lereng, batuan permukaan dalam persen, singkapan batuan dalam persen, keadaan vegetasi penutup, $\mathrm{pH}$ lapangan, kedalaman efektif tanah, dan manajemen pengelolaan tanah. Sebagai data penunjang dilakukan pencarian data kesesuaian lahan agroekonomi dengan metode wawancara baik dengan pemerintah daerah maupun kepada petani setempat.

Analisis tanah dilakukan di Laboratorium Tanah Fakultas Pertanian Universitas Udayana untuk mengetahui sifat kimia dan fisik tanah di daerah penelitian. Parameter yang diamati adalah KTK dengan metode $\mathrm{NH}_{4} \mathrm{OAc}$ $\mathrm{pH} 7, \mathrm{~KB}$ dengan metode ekstraksi 1N $\mathrm{NH}_{4} \mathrm{OAc}$ pH 7, C-organik dengan metode Walkley and Black, $\mathrm{N}$ dengan metode Kjeldahl, $\mathrm{P}$ dan $\mathrm{K}$ dengan metode bray-1, $\mathrm{pH}$ dengan metode elektometik $\mathrm{pH}$ meter, salinitas dengan metode elektrometik hantaran listrik, tekstur tanah dengan metode pipet, dan permeabilitas tanah dengan metode konsisten head.

Data hasil pengamatan fisik agroekosistem di lapangan dan data analisis sampel tanah di Laboratorium ditabulasikan ke dalam bentuk data karakteristik/kualitas lahan, penyajian data dalam bentuk data karakteristik /kualitas lahan lebih mempermudah dalam pemahaman/pembacaan data.

Penentuan kesesuaian lahan agroekosistem dilakukan dengan sistem matching, yaitu mencocokkan antara karakteristik/kualitas lahan dengan persyaratan tumbuh tanaman Djaenudin, dkk., (2000) yang di evaluasi sehingga diketahui tingkat kesesuaian lahan untuk komoditas tanaman yang dievaluasi sampai pada tingkat sub kelas.

Penentuan kesesuaian agroekonomi dengan menggunakan nilai keuntungan kotor atau gross marginal (GM) petani per ha/tahun pada tanaman yang dievaluasi, berdasarkan tabel 1 dan tabel 2. Tabel 1 memberikan informasi mengenai kelas kesesuaian lahan secara ekonomi, dengan penjelasan secara ekonomi, untuk memperoleh ring nilai gross margin dengan informasi berupa harga maka digunakan metode wawancara kepada petani di daerah penelitian pada bulan Januari tahun 2011.

Tabel 1. Kelas kesesuaian lahan secara ekonomi

\begin{tabular}{ccll}
\hline Kelas & Simbol & Kesesuaian lahan & Pengertian/keterangan \\
\hline 1 & S1 & Sangat sesuai & Secara ekonomi sangat menguntungkan \\
2 & S2 & Cukup sesuai & Secara ekonomi cukup menguntungkan \\
3 & S3 & Sesuai marjinal & Secara ekonomi marjinal menguntungkan \\
4 & N1 & $\begin{array}{l}\text { Tidak sesuai } \\
\text { sementara }\end{array}$ & $\begin{array}{l}\text { Memungkinan tetapi tanpa input tinggi } \\
\text { tidak menguntungkan (sementara) }\end{array}$ \\
& N2 & $\begin{array}{l}\text { Tidak sesuai } \\
\text { permanen }\end{array}$ & $\begin{array}{l}\text { Tidak memungkinkan dengan input tinggi } \\
\text { output yang dihasilkan tidak ekonomis }\end{array}$ \\
\hline
\end{tabular}

Sumber : Rossiter and Wambeke (1997).

Contoh kasus tanaman padi dan tanaman anggur memiliki kesesuaian agroekonomi S1 jika nilai gross margin atau keuntungan kotor petani per ha/tahun lebih dari Rp.12.000.000, kesesuaian agroekonomi S2 jika nilai gross margin menguntungkan antara Rp.1.000.000 hingga Rp.12.000.000, kesesuaian agroekonomi S3 jika nilai 
gross margin mengalami kerugian keuntungan Rp.1000.000.

Rp.1000.000 hingga mengalami

Tabel 2. Ring Nilai Gross Margin Petani per Ha/Tahun Dalam Penentuan Kelas Kesasuaian Agroekonomi

\begin{tabular}{clllll}
\hline $\begin{array}{c}\text { Kelas } \\
\text { Kesesuaian } \\
\begin{array}{c}\text { Agroekonom } \\
\text { i }\end{array}\end{array}$ & \multicolumn{1}{c}{ Padi } & \multicolumn{1}{c}{ Ring nilai ekonomi masing-masing tanaman yang dievaluasi (Rp) } \\
\cline { 2 - 6 } & \multicolumn{1}{c}{ Pisang } & \multicolumn{1}{c}{ Mangga } & Rambutan & \multicolumn{1}{c}{ Anggur } \\
\hline S1 & $>12.000 .00$ & $>30.000 .00$ & $>30.000 .00$ & $>15.000 .00$ & $>12.000 .00$ \\
& 0 & 0 & 0 & 0 & 0 \\
S2 & $1.000 .000-$ & $1.000 .000-$ & $1.000 .000-$ & $1.000 .000-$ & $1.000 .000-$ \\
& 12.000 .000 & 30.000 .000 & 30.000 .000 & 15.000 .000 & 12.000 .000 \\
S3 & $-1000.000-$ & -1.000 .000 & -1.000 .000 & -1.000 .000 & -1.000 .000 \\
& 1000.000 & -1.000 .000 & -1.000 .000 & -1.000 .000 & -1.000 .000 \\
$\mathbf{N}$ & $<-$ & $<-$ & $<-$ & $<-$ & $<-$ \\
& 1.000 .000 & 1.000 .000 & 1.000 .000 & 1.000 .000 & 1.000 .000 \\
\hline
\end{tabular}

Sumber: wawancara petani daerah penelitian (2011)

Membuat perencanaan arahan penggunaan lahan didasarkan atas kesesuaian lahan agroekosistem dan agroekonomi dan membuat peta tematik kesesuaian lahan aktual berdasarkan hasil evaluasi kesesuaian lahan agroekosistem aktual tanaman yang dievaluasi.

\section{HASIL DAN PEMBAHASAN}

Berdasarkan hasil delineasi satuan lahan homogen daerah penelitian dapat dibedakan menjadi 13 satuan lahan homogen, (tabel 3). 
Tabel 3. Satuan Lahan Daerah Penelitian

\begin{tabular}{|c|c|c|c|c|c|c|}
\hline No & $\begin{array}{l}\text { Lereng } \\
(\%)\end{array}$ & $\begin{array}{l}\text { Jenis } \\
\text { Tanah }\end{array}$ & $\begin{array}{c}\text { Penggunaan } \\
\text { Lahan }\end{array}$ & $\begin{array}{l}\text { Satuan } \\
\text { Lahan }\end{array}$ & Banjar & Desa \\
\hline 1 & $0-3$ & Regosol & Sawah & $\mathrm{ARgSw}$ & $\begin{array}{l}\text { Tegalsari, } \\
\text { Tangguwisai, } \\
\text { Kelodan, } \\
\text { Kajanan }\end{array}$ & $\begin{array}{l}\text { Tangguw } \\
\text { isia, } \\
\text { Joanyar }\end{array}$ \\
\hline 2 & $3-8$ & Regosol & Sawah & BRgSw & $\begin{array}{l}\text { Tegalsari, } \\
\text { Tangguwisai, } \\
\text { Kelodan, } \\
\text { Kajanan }\end{array}$ & $\begin{array}{l}\text { Tangguw } \\
\text { isia, } \\
\text { Joanyar }\end{array}$ \\
\hline 3 & $8-15$ & Regosol & Sawah & CRgSw & $\begin{array}{l}\text { Tegalsari, } \\
\text { Tangguwisai, } \\
\text { Kelodan, } \\
\text { Kajanan }\end{array}$ & $\begin{array}{l}\text { Tangguw } \\
\text { isia, } \\
\text { Joanyar }\end{array}$ \\
\hline 4 & $15-30$ & Regosol & Sawah & DRgSw & Kajanan & Joanyar \\
\hline 5 & $0-3$ & Regosol & $\begin{array}{l}\text { Kebun } \\
\text { campuran }\end{array}$ & ARgKc & $\begin{array}{l}\text { Kelodan, } \\
\text { Kajanan }\end{array}$ & Joanyra \\
\hline 6 & $3-8$ & Regosol & $\begin{array}{l}\text { Kebun } \\
\text { campuran }\end{array}$ & BRgKc & $\begin{array}{l}\text { Tangguwisia, } \\
\text { Kelodan, } \\
\text { Kajanan }\end{array}$ & $\begin{array}{l}\text { Tangguw } \\
\text { isia, } \\
\text { Joanyar }\end{array}$ \\
\hline 7 & $8-15$ & Regosol & $\begin{array}{l}\text { Kebun } \\
\text { campuran }\end{array}$ & CRgKc & $\begin{array}{l}\text { Tangguwisai, } \\
\text { Kelodan, } \\
\text { Kajanan }\end{array}$ & $\begin{array}{l}\text { Tangguw } \\
\text { isia, } \\
\text { Joanyar }\end{array}$ \\
\hline 8 & 1530 & Regosol & $\begin{array}{l}\text { Kebun } \\
\text { campuran }\end{array}$ & DRgKc & Kajanan & Joanyar \\
\hline 9 & $0-3$ & Regosol & Tegalan & ARgTg & $\begin{array}{l}\text { Kelodan, } \\
\text { Kajanan }\end{array}$ & Joanyar \\
\hline 10 & $3-8$ & Regosol & Tegalan & BRgTg & $\begin{array}{l}\text { Tangguwisia, } \\
\text { Kajanan }\end{array}$ & $\begin{array}{l}\text { Tangguw } \\
\text { isia, } \\
\text { joanyar }\end{array}$ \\
\hline 11 & $8-15$ & Regosol & Tegalan & CRgTg & $\begin{array}{l}\text { Kelodan, } \\
\text { Kajanan }\end{array}$ & Joanyar \\
\hline 12 & $15-30$ & Regosol & Tegalan & DRgTg & Kajanan & Joanyar \\
\hline 13 & $0-3$ & Regosol & Kebun anggur & ARgKa & Tegalsari & $\begin{array}{l}\text { Tangguw } \\
\text { isia }\end{array}$ \\
\hline
\end{tabular}

Keterangan:
A : Kelas lereng $0-3 \%$
Sw : Penggunaan Lahan Sawah Irigasi
B : Kelas lereng 3-8 \%
Kc : Penggunaan Lahan Kebun campuran
C : Kelas lereng 8-15\%
Tg : Penggunaan Lahan Tegalan
D : Kelas lereng 15-30\%
$\mathrm{Ka}$ : Penggunaan Lahan Kebun anggur
Rg : Jenis Tanah Regosol

Contoh : ARgKc maksudnya adalah, kelas lereng 0-3\%, jenis tanah Regosol, dan. penggunaan lahan kebun campuran. 
Tabel 3. Karakteristik dan Kualitas Lahan Desa Tangguwisia dan desa Joanyar, Kecamatan Seririt, Kabupaten Buleleng.

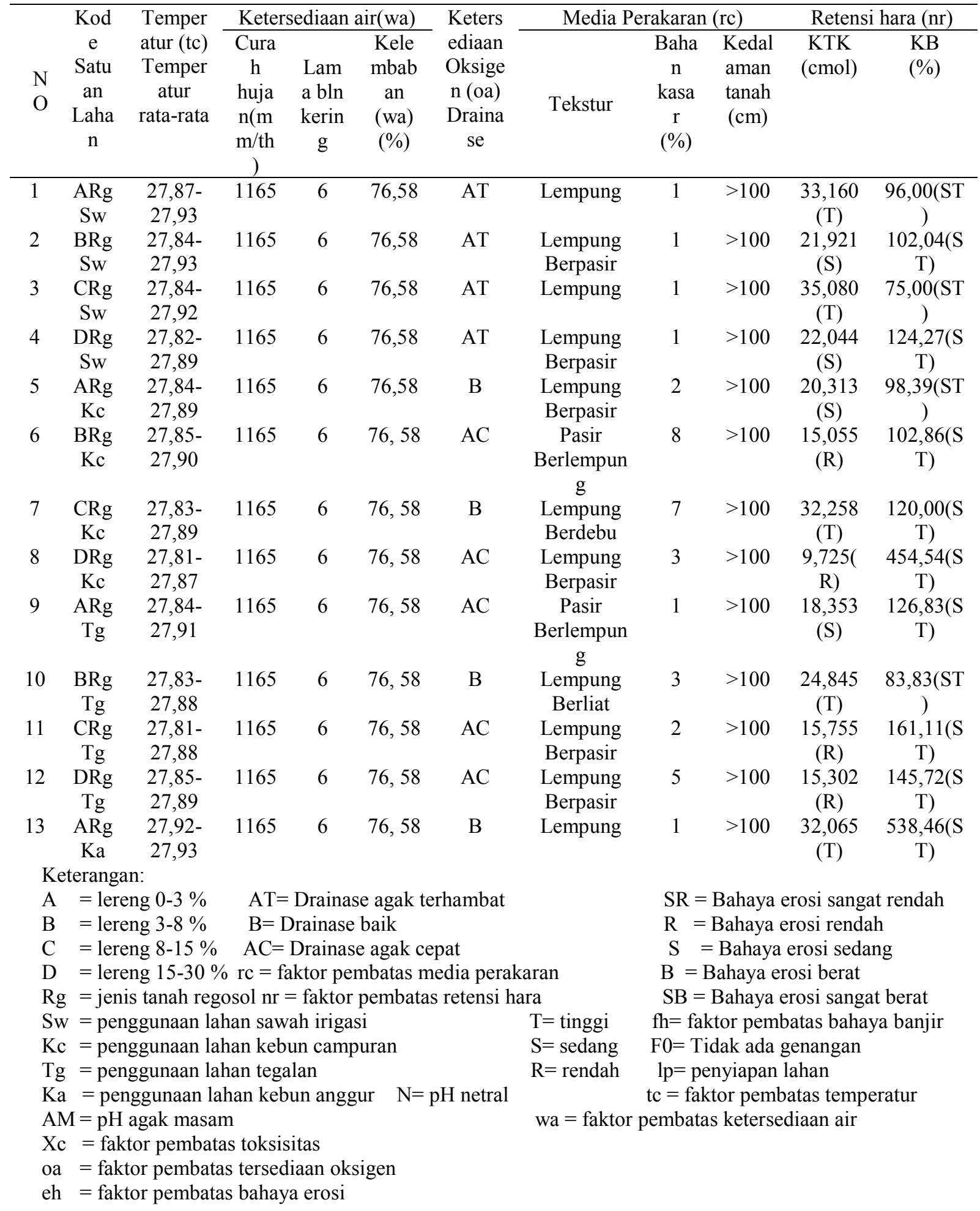


Tabel 3. Lanjutan

\begin{tabular}{|c|c|c|c|c|c|c|c|c|c|c|c|c|}
\hline \multirow[b]{2}{*}{$\begin{array}{l}\mathrm{N} \\
\mathrm{o}\end{array}$} & \multirow{2}{*}{$\begin{array}{c}\text { Kode } \\
\text { Unit } \\
\text { Lahan }\end{array}$} & \multicolumn{2}{|c|}{$\begin{array}{l}\text { Retensi hara } \\
\quad(\mathrm{nr})\end{array}$} & \multirow{2}{*}{$\begin{array}{l}\begin{array}{c}\text { Toksisita } \\
\text { s (xc) }\end{array} \\
\begin{array}{c}\text { DHL } \\
(\mathrm{mmhos} / \\
\mathrm{cm})\end{array}\end{array}$} & \multicolumn{2}{|c|}{$\begin{array}{l}\text { Bahaya erosi } \\
\text { (eh) }\end{array}$} & \multirow{2}{*}{$\begin{array}{c}\text { Bahay } \\
\text { a } \\
\text { banjir } \\
\text { (fh) } \\
\text { Genan } \\
\text { gan }\end{array}$} & \multicolumn{2}{|c|}{$\begin{array}{l}\text { Penyiapan } \\
\text { lahan (lp) }\end{array}$} & \multicolumn{3}{|c|}{ Ketersediaan Hara } \\
\hline & & $\begin{array}{l}\mathrm{pH} \\
\mathrm{H} 2 \mathrm{O}\end{array}$ & $\begin{array}{c}\text { C- } \\
\text { Organi } \\
\text { k } \\
(\%)\end{array}$ & & $\begin{array}{c}\text { Leren } \\
g \\
(\%)\end{array}$ & Erosi & & $\begin{array}{c}\text { Batuan } \\
\text { permu } \\
\text { kaan } \\
(\%)\end{array}$ & $\begin{array}{c}\text { Singk } \\
\text { apan } \\
\text { batua } \\
\text { n }(\%)\end{array}$ & $\begin{array}{l}\text { N Total } \\
(\mathrm{ppm})\end{array}$ & $\begin{array}{c}\mathrm{P} \\
\text { Tersedi } \\
\mathrm{a}(\mathrm{ppm})\end{array}$ & $\begin{array}{c}\mathrm{K} \\
\text { Tersedi } \\
\mathrm{a}(\mathrm{ppm})\end{array}$ \\
\hline 1 & $\begin{array}{c}\operatorname{ArgS} \\
\text { W }\end{array}$ & $\begin{array}{c}6,7(\mathrm{~N} \\
)\end{array}$ & $\begin{array}{c}1,723( \\
\mathrm{R})\end{array}$ & $1,380(\mathrm{R})$ & 2 & $\begin{array}{c}3,67( \\
\text { SR) }\end{array}$ & F0 & 0 & 0 & $0,110(\mathrm{R})$ & $\begin{array}{c}3,510(\mathrm{~S} \\
\mathrm{R})\end{array}$ & $27(\mathrm{SR})$ \\
\hline 2 & $\begin{array}{c}\text { BRgS } \\
\text { w }\end{array}$ & $\begin{array}{c}6,6(\mathrm{~N} \\
)\end{array}$ & $\begin{array}{c}1,307( \\
\mathrm{R})\end{array}$ & $1,800(\mathrm{R})$ & 8 & $\begin{array}{l}5,61( \\
\text { SR) }\end{array}$ & F0 & 0 & 0 & $0,050(\mathrm{SR})$ & $\begin{array}{c}88,920( \\
\text { ST) }\end{array}$ & $33(\mathrm{SR})$ \\
\hline 3 & $\begin{array}{c}\mathrm{CRgS} \\
\mathrm{w}\end{array}$ & $\begin{array}{c}6,7(\mathrm{~N} \\
)\end{array}$ & $\begin{array}{c}2,136( \\
\mathrm{S})\end{array}$ & $1,160(\mathrm{R})$ & 15 & $\begin{array}{l}4,10( \\
\text { SR) }\end{array}$ & F0 & 0 & 0 & 0,080 (SR) & $\begin{array}{c}2,410(\mathrm{~S} \\
\mathrm{R})\end{array}$ & $17(\mathrm{SR})$ \\
\hline 4 & $\begin{array}{c}\text { DRgS } \\
\text { w }\end{array}$ & $\begin{array}{c}6,7(\mathrm{~N} \\
)\end{array}$ & $\begin{array}{c}2,085( \\
\text { S) }\end{array}$ & $1,300(\mathrm{R})$ & 20 & $\begin{array}{l}8,30( \\
\text { SR) }\end{array}$ & F0 & 0 & 0 & $0,080(\mathrm{SR})$ & $\begin{array}{c}3,050(\mathrm{~S} \\
\mathrm{R})\end{array}$ & $12(\mathrm{SR})$ \\
\hline 5 & $\begin{array}{c}\operatorname{ArgK} \\
\mathrm{c}\end{array}$ & $\begin{array}{l}6,3(\mathrm{~A} \\
\mathrm{M})\end{array}$ & $\begin{array}{l}0,846( \\
\text { SR) }\end{array}$ & $1,280(\mathrm{R})$ & 5 & $\begin{array}{l}51,92 \\
(\mathrm{R})\end{array}$ & F0 & 0 & 0 & $0,030(\mathrm{SR})$ & $\begin{array}{c}27,00(\mathrm{~T} \\
)\end{array}$ & $27(\mathrm{SR})$ \\
\hline 6 & $\begin{array}{c}\mathrm{BRgK} \\
\mathrm{c}\end{array}$ & $\begin{array}{c}6,6(\mathrm{~N} \\
)\end{array}$ & $\begin{array}{c}0,838( \\
\text { SR) }\end{array}$ & $\begin{array}{c}0,940 \text { (SR } \\
\text { ) }\end{array}$ & 8 & $\begin{array}{l}68,81 \\
(\mathrm{~S})\end{array}$ & F0 & 0 & 0 & $0,020(\mathrm{SR})$ & $\begin{array}{c}2,360(\mathrm{~S} \\
\mathrm{R})\end{array}$ & $10(\mathrm{SR})$ \\
\hline 7 & $\begin{array}{c}\mathrm{CRgK} \\
\mathrm{c}\end{array}$ & $\begin{array}{c}6,8(\mathrm{~N} \\
)\end{array}$ & $\begin{array}{c}1,347( \\
\mathrm{R})\end{array}$ & $1,020(\mathrm{R})$ & 10 & $\begin{array}{l}145,0 \\
4(B)\end{array}$ & F0 & 10 & 0 & $0,030(\mathrm{SR})$ & $\begin{array}{c}3,280(\mathrm{~S} \\
\mathrm{R})\end{array}$ & $34(\mathrm{SR})$ \\
\hline 8 & $\begin{array}{l}\mathrm{DRg} \\
\mathrm{Kc}\end{array}$ & $\begin{array}{c}6,9(\mathrm{~N} \\
)\end{array}$ & $\begin{array}{c}0,872( \\
\text { SR) }\end{array}$ & $1,330(\mathrm{R})$ & 25 & $\begin{array}{c}331,8 \\
3(\mathrm{~B})\end{array}$ & F0 & 0 & 0 & $0,030(\mathrm{SR})$ & $\begin{array}{c}3,150(\mathrm{~S} \\
\mathrm{R})\end{array}$ & $21(\mathrm{SR})$ \\
\hline 9 & $\underset{\mathrm{g}}{\operatorname{ArgT}}$ & $\begin{array}{c}6,7(\mathrm{~N} \\
)\end{array}$ & $\begin{array}{c}0,872( \\
\text { SR) }\end{array}$ & $1,020(\mathrm{R})$ & 1 & $\begin{array}{c}23,86 \\
(\mathrm{R})\end{array}$ & F0 & 0 & 0 & $0,010(\mathrm{SR})$ & $\begin{array}{c}2,820(\mathrm{~S} \\
\mathrm{R})\end{array}$ & $38(\mathrm{SR})$ \\
\hline 10 & $\begin{array}{l}\text { BRgT } \\
\mathrm{g}\end{array}$ & $\begin{array}{l}6,4(\mathrm{~A} \\
\mathrm{M})\end{array}$ & $\begin{array}{c}1,210( \\
\mathrm{R})\end{array}$ & $1,110(\mathrm{R})$ & 6 & $\begin{array}{c}21,04 \\
(\mathrm{R})\end{array}$ & F0 & 0 & 0 & $0,050(\mathrm{SR})$ & $\begin{array}{c}3,280(\mathrm{~S} \\
\mathrm{R})\end{array}$ & $38(\mathrm{SR})$ \\
\hline 11 & $\begin{array}{c}\text { CRgT } \\
\text { g }\end{array}$ & $\begin{array}{c}6,7(\mathrm{~N} \\
)\end{array}$ & $\begin{array}{c}1,279( \\
\mathrm{R})\end{array}$ & $1,320(\mathrm{R})$ & 13 & $\begin{array}{c}131,3 \\
4(\mathrm{~S})\end{array}$ & F0 & 10 & 0 & $0,040(\mathrm{SR})$ & $\begin{array}{c}117,110 \\
(\mathrm{ST})\end{array}$ & 73(SR) \\
\hline 12 & $\begin{array}{l}\mathrm{DRgT} \\
\mathrm{g}\end{array}$ & $\begin{array}{c}6,8(\mathrm{~N} \\
)\end{array}$ & $\begin{array}{c}0,852( \\
\text { SR) }\end{array}$ & $1,710(\mathrm{R})$ & 20 & $\begin{array}{l}257,8 \\
1(\mathrm{~B})\end{array}$ & F0 & 5 & 0 & $0,030(\mathrm{SR})$ & $\begin{array}{c}22,990( \\
\mathrm{S})\end{array}$ & $19(\mathrm{SR})$ \\
\hline 13 & $\begin{array}{c}\operatorname{ArgK} \\
\mathrm{a}\end{array}$ & $\begin{array}{c}6,5(\mathrm{~N} \\
)\end{array}$ & $\begin{array}{c}2,260( \\
S)\end{array}$ & $2,070(\mathrm{~S})$ & 2 & $\begin{array}{c}26,44 \\
(\mathrm{~S})\end{array}$ & F0 & 0 & 0 & $0,090(\mathrm{SR})$ & $\begin{array}{c}35,710( \\
\text { ST) }\end{array}$ & $18(\mathrm{SR})$ \\
\hline
\end{tabular}

Hasil evaluasi kesesuaian lahan tanaman padi sawah irigasi yaitu kelas kesesuaian lahan Agroekosistem aktual S2 (cukup sesuai) terdapat pada satuan lahan $\mathrm{ARgSw}$ dengan faktor pembatas tekstur, kelas kesesuaian lahan aktual S3 (sesuai marginal) terdapat pada satuan lahan $\mathrm{BRgSw}$ dengan faktor pembatas lereng, dan kesesuaian lahan aktual $\mathrm{N}$ terdapat pada satuan lahan $\mathrm{CRgSw}$ dan DRgSw dengan faktor pembatas lereng. Daerah penelitian telah menerapkan teras bangku namun teras bangku yang ada masih dapat diperbaiki sehingga kelas kesesuaian lahan potensialnya dapat meningkat.
Kelas kesesuaian lahan aktual S2 (cukup sesuai) terdapat pada satuan lahan $\mathrm{ARgSw}$ dengan faktor pembatas tekstur, faktor pembatas tekstur meskipun sulit diperbaiki namun masih dapat diatasi dengan penambahan bahan organik, dengan penambahan bahan organik dipermukaan mampu memperbaiki sifat fisik dan sifat kimia tanah bagian permukaan, sehingga kelas kesesuaian lahan potensial meningkat menjadi S1 (sangat sesuai). Kelas kesesuaian lahan aktual S3 terdapat pada satuan lahan $\mathrm{BRgSw}$ dengan faktor pembatas tekstur dan lereng, faktor pembatas tekstur dapat diatasi 
dengan penambahan bahan organik, sedangkan faktor pembatas lereng dapat diatasi dengan perbaikan teras bangku yang sudah ada sehingga kelas kesesuaian lahan potensial meningkat menjadi S2 dengan faktor pembatas tekstur, lereng, dan C-organik. Kelas kesesuaian lahan aktual $\mathrm{N}$ terdapat pada satuan lahan $\mathrm{CRgSw}$ dan $\mathrm{DRgSw}$ dengan faktor pembatas lereng, faktor pembatas lereng dapat diatasi dengan perbaikan teras bangku yang sudah ada sehingga kelas kesesuaian lahan potensial $\mathrm{CRgSw}$ meningkat menjadi S2, sedangkan DRgSw meningkat menjadi S3, dengan faktor pembatas tekstur dan lereng.

Hasil evaluasi kesesuaian lahan potensial dan aktual untuk tanaman pisang yaitu kelas kesesuaian lahan aktual untuk tanaman pisang S3 pada satuan lahan $\mathrm{ARgKc}, \mathrm{CRgKc}, \mathrm{DRgKc}$, BRgTg, CRgTg, DRgTg, dan ARgKa dengan faktor pembatas curah hujan, lama bulan kering, tekstur, lereng, dan erosi. Kelas kesesuaian lahan aktual N pada satuan lahan $\mathrm{BRgKb}$, dan $\mathrm{ARgTg}$ dengan faktor pembatas tekstur yang kasar. Kelas kesesuaian lahan aktual S3 terdapat di satuan lahan ARgKc, CRgKc, DRgKc, BRgTg, CRgTg, DRgTg, dan ARgKa dengan faktor pembatas curah hujan, lama bulan kering, tekstur, lereng, dan erosi, faktor pembatas kualitas lahan ketersediaan air seperti curah hujan dan lama bulan kering sangat sulit untuk diperbaiki namun karena terdapat sumber air di daerah penelitian seperti dekat dengan sungai yang mengalir sepanjang tahun sehingga faktor pembatas oleh kualitas lahan ketersediaan air (curah hujan dan lama bulan kering) dapat diatasi dengan penerapan sistem irigasi, dengan pengairan yang teratur, dan penambahan mulsa, faktor pembatas kualitas lahan media perakaran (tekstur) dapat diatasi dengan penambahan bahan organik, faktor pembatas kualitas lahan bahaya erosi dapat diperbaiki dengan pembuatan teras bangku dan penanaman tanaman pagar/penguat teras, menurut Adiningsih dan Mulyadi peranan tanaman pagar disamping untuk menyediakan bahan organik juga untuk mencegah bahaya erosi, kelas kesesuaian lahan potensial menjadi S2 pada satuan lahan $\mathrm{ARgKc}, \mathrm{CRgKc}$, DRgKc, BRgTg, CRgTg, DRgTg, dan ARgKa dengan faktor pembatas Temperatur, Curah hujan, lama bulan kering, drainase, Tekstur, lereng, erosi, KTK, C-organik, salinitas, dan batuan permukaan. Kelas kesesuaian lahan aktual $\mathrm{N}$ terdapat di satuan lahan $\mathrm{BRgKc}$, dan ARgTg dengan faktor pembatas tekstur, faktor pembatas tekstur dapat diatasi dengan penambahan bahan organik, sehingga kelas kesesuaian lahan potensial meningkat menjadi S3 dengan faktor pembatas curah hujan, lama bulan kering, dan tekstur.

Hasil evaluasi kesesuaian lahan aktual dan potensial untuk tanaman mangga yaitu kelas kesesuaian lahan aktual untuk tanaman mangga adalah S2 di satuan lahan $\mathrm{CRgKc}, \mathrm{BRgTg}$, dan ARgKa dengan faktor pembatas curah hujan, lereng, erosi, KTK, dan batuan permukaan. Kelas kesesuaian lahan aktual S3 terdapat di satuan lahan ARgKc, DRgKc, CRgTg, dan DRgTg dengan faktor pembatas pembatas curah hujan, drainase, tekstur, lereng, dan erosi. Kelas kesesuaian lahan aktual $\mathrm{N}$ terdapat pada satuan lahan $\mathrm{BRgKc}$ dan ARgTg dengan faktor pembatas tekstur. Kelas kesesuaian lahan aktual S2 terdapat di satuan lahan $\mathrm{CRgKc}$, $\mathrm{BRgTg}$, dan $\mathrm{ARgKa}$ dengan faktor pembatas curah hujan, lereng, erosi, dan batuan permukaan, faktor pembatas kualitas lahan ketersediaan air (curah hujan) meskipun sulit diatasi namun karena daerah penelitian berdekatan 
dengan sungai yang mengalir sepanjang tahun maka dapat diatasi dengan pembuatan sistem irigasi, pengairan, dan penambahan mulsa, faktor pembatas kualitas lahan bahaya erosi (lereng dan erosi) dapat diatasi dengan pembuatan teras bangku dan penanaman tanaman pagar, Menurut LREP II perbaikan faktor pembatas bahaya erosi dengan pembuatan teras bangku dapat meningkatkan 1 level kesesuaian lahan, faktor pembatas kualitas lahan retensi hara (KTK) dapat ditingkatkan dengan penambahan bahan organik, untuk menghilangkan batuan permukaan dapat dilakukan pembersihan batu-batu permukaan, menurut Hardjowigeno membersihkan batu-batu di permukaan adalah perbaikan yang dapat dilakukan sendiri dan memiliki efek kecil atau tidak permanen, sehingga kelas kesesuaian lahan potensialnya menjadi S1(sangat sesuai). Kelas kesesuaian lahan aktual S3 terdapat pada satuan lahan ARgKc, DRgKc, CRgTg, dan DRgTg dengan faktor pembatas pembatas curah hujan, drainase, tekstur, lereng, dan erosi, faktor pembatas curah hujan dapat diatasi dengan pembuatan sistem irigasi, pengairan, dan penambahan mulsa, untuk mengatasi faktor pembatas oleh kualitas lahan ketersediaan oksigen (drainase yang cepat) dapat diatasi dengan penambahan bahan organik dan penambahan mulsa, faktor pembatas tekstur dapat diatasi dengan penambahan bahan organik, sehingga kelas kesesuaian lahan potensial menjadi S2 dengan faktor pembatas Curah hujan, drainase, tekstur, lereng, erosi, KTK, C-organik, batuan permukaan. Kelas kesesuaian lahan aktual $\mathrm{N}$ terdapat pada satuan lahan BRgKc dan ARgTg dengan faktor pembatas tekstur yang kasar, faktor pembatas tekstur dapat diatasi dengan penambahan bahan organik, sehingga kelas kesesuaian lahan potensial menjadi S3 dengan faktor pembatas drainase yang agak cepat dan tekstur yang kasar.

Hasil evaluasi kesesuaian lahan aktual dan potensial untuk tanaman rambutan dan durian adalah $\mathrm{N}$ (tidak sesuai) pada satuan lahan ARgKc, BRgKc, CRgKc, DRcKc, ARgTg, BRgTg, CRgTg, DRgTg, dan ARgKa dengan faktor pembatas kualitas lahan ketersediaan air yaitu karakteristik lahan curah hujan, dan kualitas lahan media perakaran yaitu karakteristik lahan tekstur, faktor curah hujan dan tekstur, faktor pembatas kualitas lahan ketersediaan air (karakteristik lahan curah hujan) meskipun sulit diatasi namun karena daerah penelitian berdekatan dengan sungai yang mengalir sepanjang tahun maka dapat diatasi dengan penerapan sistem irigasi, pengairan yang teratur, dan penambahan mulsa, faktor pembatas kualitas lahan media perakaran (karakteristik lahan tekstur) dapat diatasi dengan penambahan bahan organik, sehingga kelas kesesuaian lahan potensial menjadi S3 dengan faktor pembatas Curah hujan, draenase, tekstur, lereng, dan erosi.

Kesesuaian lahan selain ditentukan secara fisik, kelas kesesuaian lahan juga bisa ditentukan dari indeks ekonomi. Bagaimana indeks ekonomi dapat ditentukan dari beberapa data, yaitu data keuntungan kotor atau gross margin (GM), nilai bersih akhir usaha atau Net Present Value (NPV), rasio keuntungan terhadap biaya atau Benefit Cost Ratio $(B / C)$. Namun kesesuaian lahan secara ekonomi memiliki kekurangan yaitu sifatnya kondisional bergantung pada situasi dan peluang pasar (Rossiter and Wambeke, 1997). Kesesuaian agroekonomi tanaman Padi S1 (sangat sesuai) pada satuan lahan $\mathrm{ARgSw}$, $\mathrm{BRgSw}$, dan $\mathrm{CRgSw}$ dengan nilai groos margin petani per ha/tahun 
Rp.15.720.000 sampai dengan Rp.17.550.000, nilai tersebut berdasarkan ring nilai gross margin petani per ha/tahun untuk tanaman padi (tabel 2) lebih dari Rp.12.000.000, dan secara ekonomi sangat menguntungkan sehingga dikategorikan sebagai kesesuaian agroekonomi S1. Kesesuaian agroekonomi tanaman padi S2 (cukup sesuai) pada satuan lahan $\mathrm{DRgSw}$ dengan nilai gross margin petani per ha/tahun sebesar Rp.9.700.000, untuk tanaman padi (tabel 2) antara Rp.1.000.000 hingga Rp.12.000.000 secara ekonomi masih cukup menguntungkan sehingga dikategorikan sebagai kesesuaian agroekonomi S2. Kesesuaian agroekonomi tanaman pisang S1 pada satuan lahan $\mathrm{ARgKc}$, BRgKc, DRgKc, dan DRgTg dengan nilai gross margin petani per ha/tahun Rp.45.000.000 sampai dengan Rp.65.000.000. Kesesuaian agroekonomi tanaman pisang S2 terdapat pada satuan lahan $\mathrm{CRgKc}$, ARgTg, BRgTg, dan CRgTg memiliki nilai gross margin petani per ha/tahun Rp.12.000.000 sampai dengan Rp.26.000.000. Sedangkan pada satuan lahan ARgKa tidak ditemukan adanya tanaman pisang. Kesesuaian agroekonomi tanaman mangga S1 pada satuan lahan ARgTg, dan CRgTg dengan nilai gross margin petani per ha/tahun Rp.43.000.000 sampai dengan Rp.65.000.000.

Kesesuaian

\section{SIMPULAN}

1. Kelas kesesuaian agroekosistem aktual tanaman padi adalah S2, $\mathrm{S} 3$, dan $\mathrm{N}$ dengan faktor pembatas tekstur dan lereng. Kelas kesesuaian agroekosistem potensial adalah $\mathrm{S} 1, \mathrm{~S} 2$, dan $\mathrm{S} 3$ dengan faktor pembatas tekstur, lereng, dan C-organik.

2. Kelas kesesuaian agroekosistem aktual tanaman pisang S3 dan $\mathrm{N}$ agroekonomi tanaman mangga S2 terdapat pada satuan lahan DRgKc, BRgTg, dan DRgTg dengan nilai gross margin petani per ha/tahun Rp.13.000.000 sampai dengan Rp.19.000.000. Sedangkan pada satuan lahan ARgKc, BRgKc, CRgKc, dan ARgKa tidak ditemukan adanya tanaman mangga yang dibudidayakan. Kesesuaian agroekonomi tanaman rambutan S1 pada satuan lahan ARgKc dengan nilai gross margin petani per ha/tahun Rp.20.000.000. Kesesuaian agroekonomi tanaman rambutan S2 terdapat pada satuan lahan $\mathrm{ARgTg}$, dan BRgTg memiliki nilai gross margin petani per ha/tahun Rp.8.5000.000 sampai dengan Rp.10.000.000. Satuan lahan BRgKc, CRgKc, DRgKc, CRgTg, DRgTg, dan ARgKa tidak ditemukan adanya tanaman rambutan yang dibudidayakan. Kesesuaian agroekonomi tanaman durian tidak dapat diperoleh karena tidak ditemukan adanya data keuntungan ekonomi tanaman durian pada semua satuan lahan karena sangat sedikit yang dibudidayakan dan usianya belum mencapai usia produksi di daerah penelitian. Kesesuaian agroekonomi tanaman Anggur S1 pada satuan lahan ARgKa dengan nilai gross margin petani per ha/tahun Rp.15.300.750, satuan lahan lainnya tidak ditemukan adanya tanaman anggur yang dibudidayakan.

dengan faktor pembatas curah hujan, lama bulan kering, tekstur, lereng, dan erosi. Kelas kesesuaian agroekosistem potensial adalah S2, dan S3 dengan faktor pembatas temperatur, curah hujan, lama bulan kering, tekstur, lereng, erosi, C-organik, KTK, salinitas, dan batuan permukaan. 
3. Kelas kesesuaian agroekosistem aktual tanaman mangga adalah S2, $\mathrm{S} 3$, dan $\mathrm{N}$ dengan faktor pembatas curah hujan, tekstur, lereng, batuan permukaan, dan erosi. Kelas kesesuaian agroekosistem potensial S1, S2, dan S3 dengan faktor pembatas Curah hujan, drainase, tekstur, lereng, erosi, KTK, C-organik, batuan permukaan.

4. Kelas kesesuaian agroekosistem aktual tanaman rambutan dan durian $\mathrm{N}$ dengan faktor pembatas curah hujan, dan tekstur. Kelas kesesuaian agroekosistem potensial S3 dengan faktor pembatas curah hujan, draenase, tekstur, lereng, dan erosi.

5. Kelas kesesuaian agroekosistem aktual tanaman anggur S2, S3, dan

\section{DAFTAR PUSTAKA}

Adiningsih, J.S., dan Mulyadi. 1993. Alternatif teknik rehabilitasi dan pemanfaatan lahan alang-alang. Halaman 29-50 dalam Prosiding Seminar Pemanfaatan lahan Alang-alang untuk Usaha Berkelanjutan. Pusat Penelitian Tanah dan Agroklimat, Bogor.

Badan Pusat Statistik. 2009. Kecamatan Seririt Dalam Angka 2009. Badan Pusat Statistik, Kabupaten Buleleng.

DPU. 1990. Pedoman Teknik Penataan

Ruang Daerah. Direktorat Jendral Cipta Karya. Depertemen Pekerjaan Umum.

Djaenudin D., Marwah, H., H. Subagyo, A. Mulyani, dan Nata Suharta. 2000. Kriteria Kesesuaian Lahan untuk Komoditas Pertanian. Versi 3.0. September 2000. Puslittanak, Badan Litbang Pertanian.
$\mathrm{N}$ dengan faktor pembatas lama bulan kering, tekstur, drainase, lereng, dan erosi. Kelas kesesuaian agroekosistem potensial adalah $\mathrm{S} 1, \mathrm{~S} 2$, dan S3 dengan faktor pembatas lama bulan kering, draenase, tekstur, lereng, erosi, KTK, dan batuan permukaan.

6. Kesesuaian agroekonomi tanaman padi, pisang, mangga, rambutan, dan durian adalah S1 dan S2. Kesesuaian agroekonomi untuk tanaman anggur adalah S1.

\section{UCAPAN TERIMA KASIH}

Pada kesempatan ini penulis ingin mengucapkan terima kasih kepada semua pihak yang telah membantu dengan caranya masing-masing dalam melengkapi tulisan ini.

FAO. 1976. A Framework for Land Evaluation. Soils Bulletin No. S12. FAO Rome.

FAO. 1999. Land Evaluation and Farming System Analysis for Land Use Planning. FAO Rome, Italy. Food and Agriculture Organization of the Satuaned Nations. FAO working Doc. 3rd edition.

Hardjowigeno, S. dan Widiatmaka. 2007. Kesesuaian Lahan dan Perencanaan Tataguna Tanah. Jurusan Tanah Fakultas Pertanian Universitas Gadjah Mada. Yogyakarta.

Jayadinata, Johara T. 1992. Tata Guna Tanah dalam Perencanaan Perdesaan Perkotaan dan Wilayah, Penerbit ITB, Bandung.

LPHPT. 2011. Data Klimatologi Stasiun Tangguwisia Sepuluh Tahun Terakhir. LPHPT Tangguwisia.

LREP II. 1994. Kesesuaian Lahan untuk Tanaman Pertanian dan 
Tanaman Kehutanan. Centre for Soil and Agroclimate Research. Bogor.

PUSLITANAK. 1993. Petunjuk Teknis Evaluasi Lahan. Pusat Penelitian Tanah dan Agroklimat.

Rahman, D. 1990. Informasi Sumberdaya Lahan sebagai Dasar Penyusunan Struktur Tata Ruang Propinsi Sumatera Selatan. Seminar/Diskusi RePPMIT di Bappeda Propinsi DT.I Sumatera Selatan, Tgl. 18-9-1990 di Palembang.

Rahman, D. 1992. Land Evalation Methods for Perenial Crops : Scripts. Rulal and land Ecology Survey. International Institute for Aerospace Survey and Earth Sciencies (ITC). Enshede. The Netherland.

Rossiter, D. G. 1994. Land Evaluation. Lecture Note. College of
Agriculture and Life Science. Dept. of Soil, Crop \& Atmospheric Science. SCAS Teaching Series T94-S1.

Rossiter, D. G., and A. R. van Wambeke. 1997. Automated Land Evaluation System ALES Version 4.65d User's Manual. Cornel Univ. Dept of Soil Crop \& Atmospheric Sci. SCAS. Ithaca NY, USA.

Sitorus, S.R.P., 2004. Evaluasi Sumberdaya Lahan. Tarsito. Bandung.

Zaini, Z., dan Z. Lamid. 1993. Alternatif teknologi budidaya tanaman pangan pada lahan alang-alang. Halaman 71-102 dalam Prosiding Seminar Pemanfaatan lahan Alang-alang untuk Usaha Berkelanjutan. Pusat penelitianTanah dan Agroklimat, Bogo 


\section{LAMPIRAN}

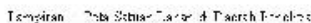

PETA SATUAN LAHAN DI DESA TANGGUWISIA DAN DESA JOANYAR, KECAMATAN SERIRT, KABUPATEN BULELENG

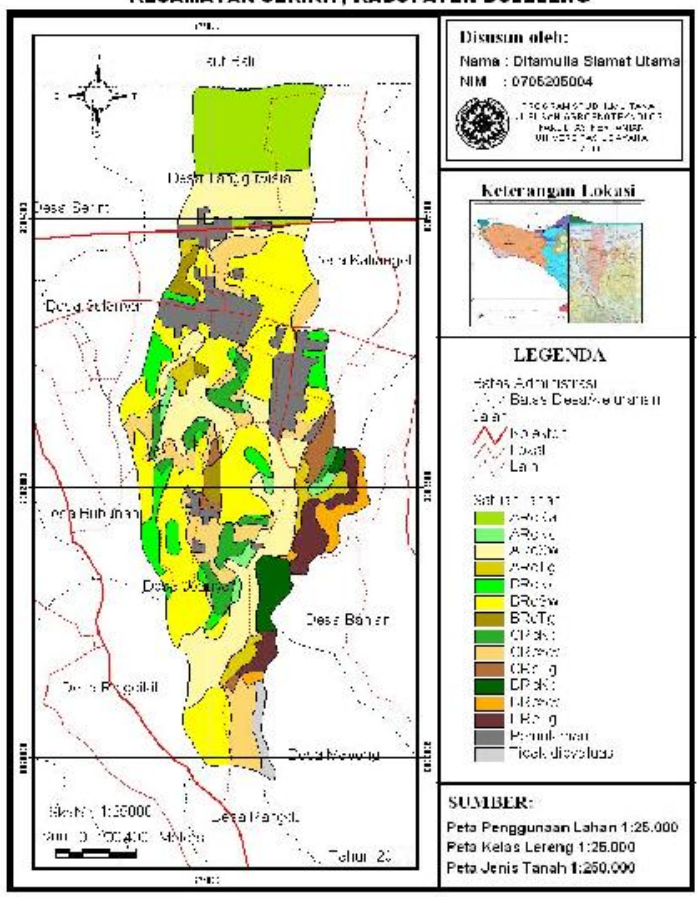

PETA KESESUAIAN LAHAN AKTUAL TANAMAN PISANG DI DESA TANGGUWISIA DAN DESA JOANYAR, KECAMATAN SERIRIT, KABUPATEN BULELENG

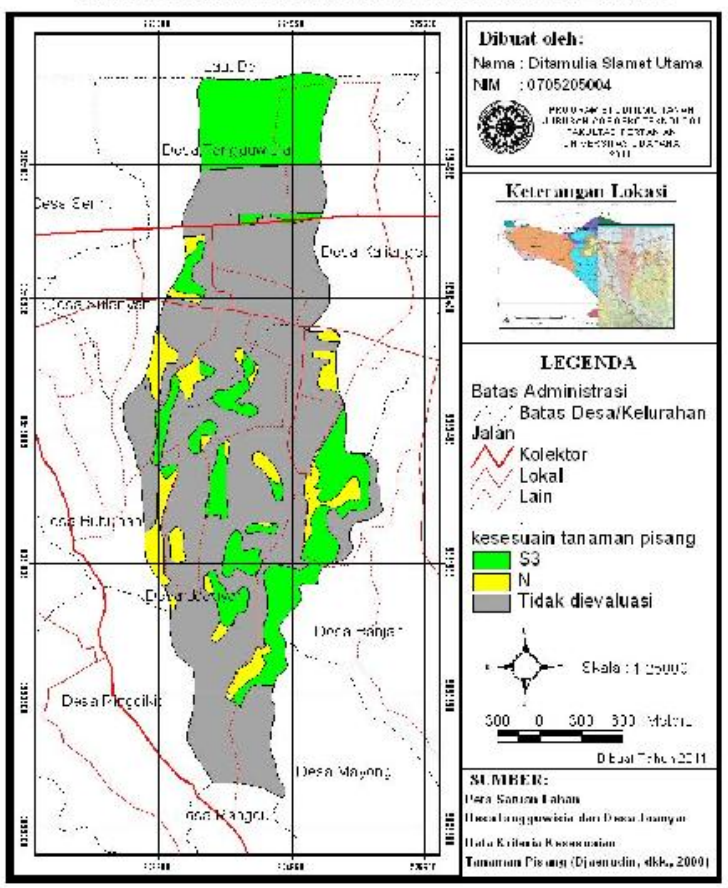

PETA KESESUAIAN LAHAN AKTUAL TANAMAN PADI DI DESA TANGGUWISIA DAN DESA JOANYAR, KECAMATAN SERIRIT, KABUPATEN BULELENG

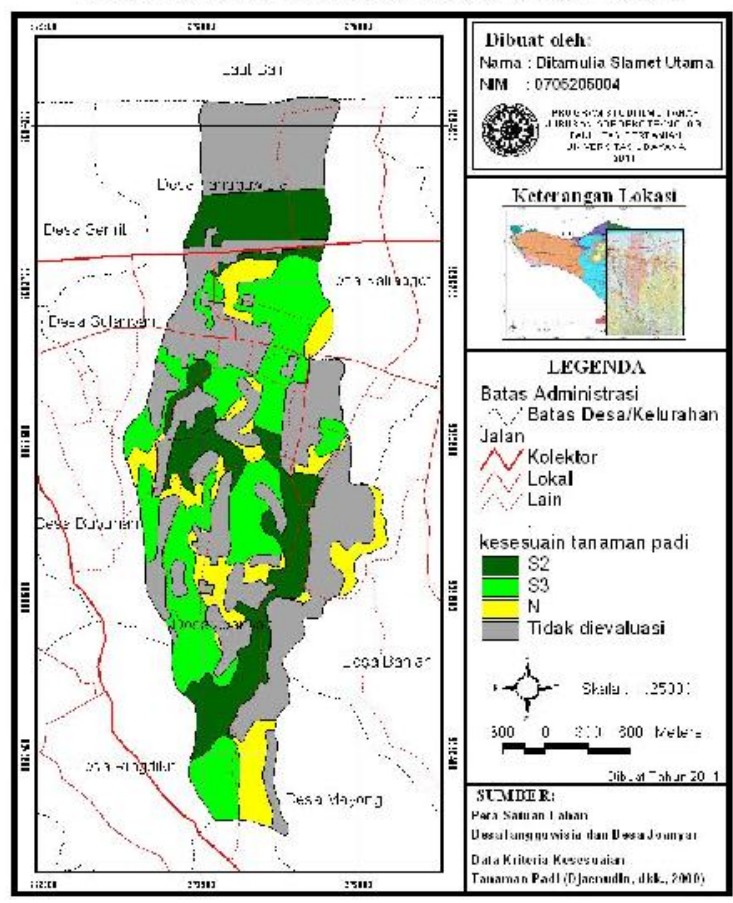

PETA KESESUAIAN LAHAN AKTUAL TANAM AN MANGGA DI DESA TANGGUWISIA DAN DESA JOANYAR, KECAMATAN SERIRIT, KABUPATEN BULELENG

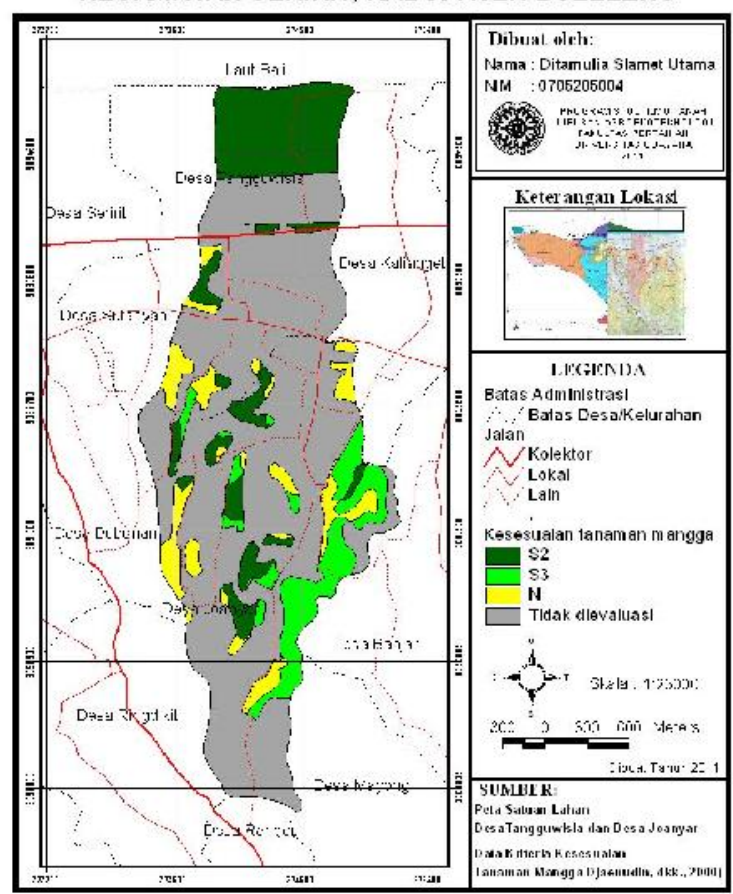



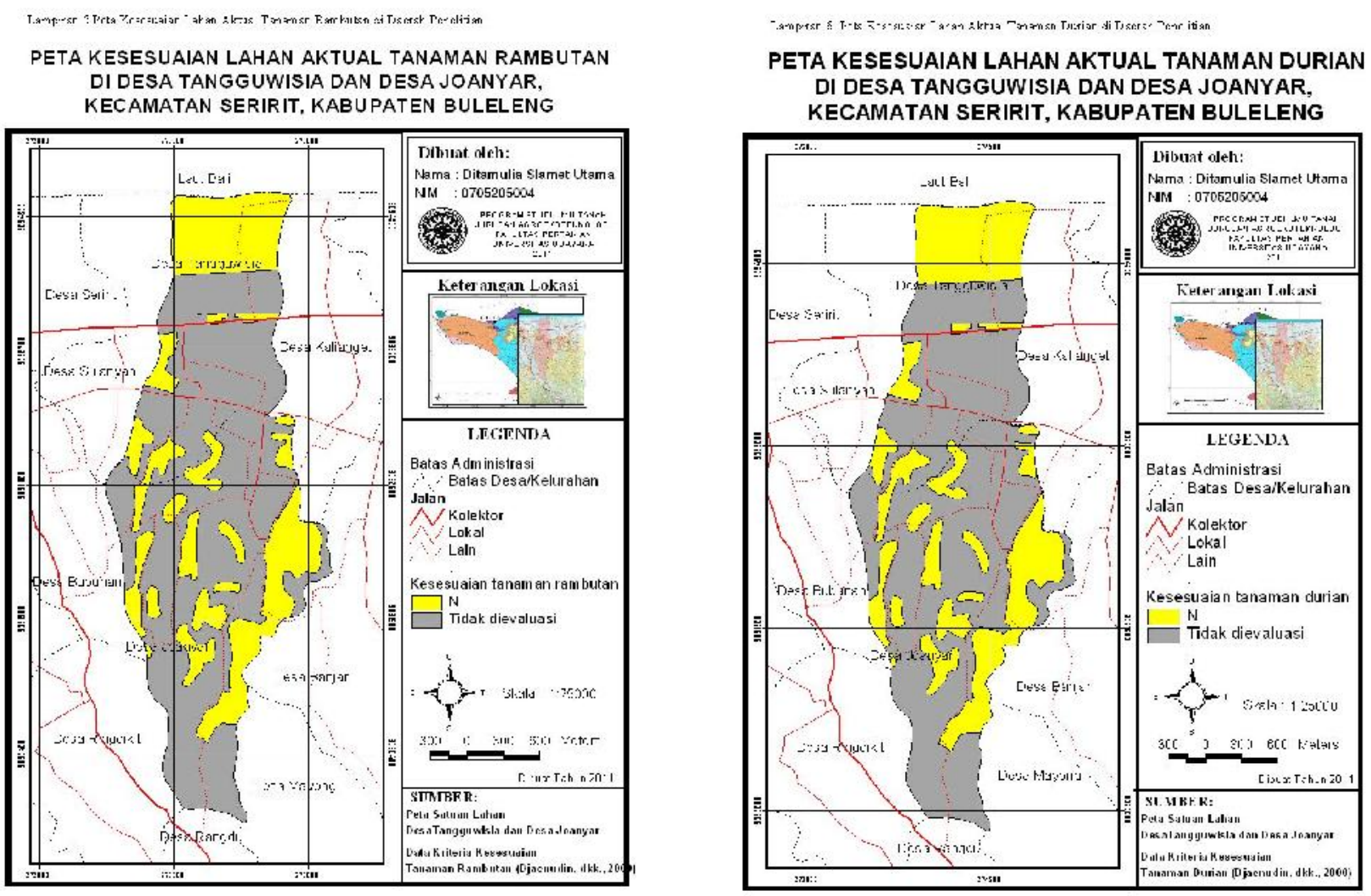

PETA KESESUAIAN LAHAN AKTUAL TANAMAN ANGGUR DI DESA TANGGUWISIA DAN DESA JOANYAR, KECAMATAN SERIRIT, KABUPATEN BULELENG

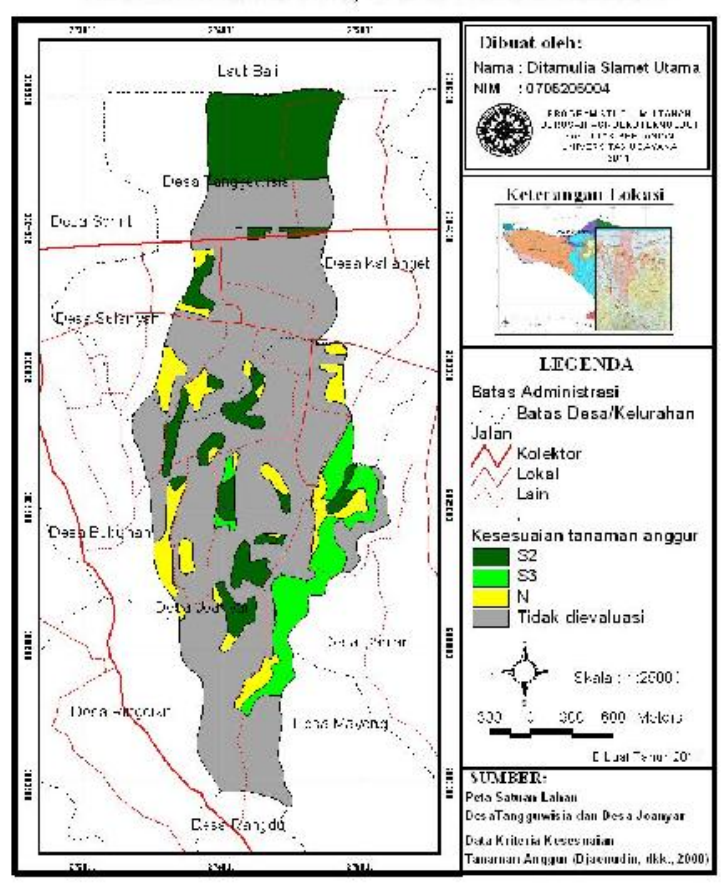

